\title{
Adiponectin, IL-6 and hsCRP: Interplay of Inflammation with Obesity and Type 2 Diabetes in Indian Population
}

\author{
Deepy Zohmangaihi ${ }^{*}$, SB Sharma ${ }^{2}$ SV Madhu ${ }^{2}$ \\ ${ }^{1}$ Department of Biochemistry, Postgraduate Institute of Medical Education $\mathcal{E}$ Research, Chandigarh, India; ${ }^{2}$ Departments of Biochemistry \\ and Medicine, University College of Medical Science $\mathcal{E}$ Guru Teg Bahadur Hospital, Delhi, India
}

\begin{abstract}
Purpose: To identify the association if any, of inflammatory markers (IL-6 and hsCRP) with adiponectin in obese diabetic, non-obese diabetic, obese non-diabetic and healthy (control) people in North Indian population.

Materials and methods: Total 88 volunteers were distributed in 4 groups: obese diabetic, non-obese diabetic, obese non-diabetic and healthy controls. The blood chemistry parameters were analyzed and serum adiponectin, IL-6 and hsCRP levels were measured by ELISA.

Result: Significant reduction was observed in serum adiponectin levels in obese and diabetic group as compared with healthy population. Similarly, significant increase was observed in IL-6 and hs CRP levels in obese and diabetic groups compared with healthy control group.

Conclusion: From our data it can be summarized that there is a significant change in both adiponectin (reduction) and IL-6 and hsCRP (increase) levels in obese diabetic, non-obese diabetic and obese non-diabetic people in Indian population. The result of our study showed that adiponectin levels are reduced in obesity and type-2 diabetes, and there is a reciprocal association of hsCRP and IL-6 in the above conditions.
\end{abstract}

Keywords: Diabetes; Nonhuman primate; Beta cell; Diabetes progression

\section{INTRODUCTION}

Inflammation plays a significant role in human health [1]. Optimal level of inflammation is required for immunity enhancement while chronic inflammation is associated with several metabolic disorders like type 2 diabetes, obesity, cardiovascular disease, etc. Though inflammation and type 2 diabetes are directly associated, the cause and effect is not well defined. Several reports have indicated that the progression and severity of the metabolic disorders are well correlated with increased level of inflammatory parameters [2]. It may be hypothesized that in healthy population, change in proinflammatory markers should be compensated by altered antiinflammatory markers; any deviation from this profile would lead to systemic disorder. The important regulators in this context of metabolic disorders are adiponectin, IL-6 and hsCRP. Adiponectin is a 244 amino acid long protein that is secreted from adipocytes with anti-inflammatory and insulin-sensitizing property [3]. The other members are pro-inflammatory cytokines IL- 6 and hsCRP which are known to be elevated in diabetes. These markers though well understood in terms of their regulation in diabetes population are still lacking acceptance as clinical markers due to the variation of levels among various ethnic groups [4]. In recent times, the numbers of diabetic and obese people has increased significantly in developing and emerging countries like India and China. Various metagenomic studies indicated the association of common gene variants encoding adipokines and inflammatory markers with adiposity in Asian Indian and role of truncal obesity accounting for the 2-fold excess incidence of diabetes in Asian Indians [5,6]. In this study, we focused on the importance of inflammation on type 2 diabetes and investigated its association with adiponectin and obesity, we highlighted the role of inflammatory regulators hsCRP and IL- 6 with adiponectin in type 2 diabetes and obesity in Indian population.

\section{MATERIALS AND METHODS}

The study was carried out in the Departments of Biochemistry and Medicine at University College of Medical Sciences and GTB Hospital, Delhi for a period of 18 months. Diagnosis of type 2 diabetes was based on Revised American Diabetes Association

Correspondence to: Dr. Deepy Zohmangaihi, Department of Biochemistry, Postgraduate Institute of Medical Education \& Research, Chandigarh, India, Tel: + 9184148 63196; E-mail: drdeepyz14@gmail.com

Received: January 11, 2019, Accepted: March 16, 2019, Published: March 25, 2019

Citation: Zohmangaihi D, Sharma SB, Madhu SV (2019) Adiponectin, IL-6 and hsCRP: Interplay of Inflammation with Obesity and Type 2 Diabetes in Indian Population. J Diabetes Metab. 10:822. doi: 10.35248/2155-6156.19.10.822

Copyright: $@ 2019$ Zohmangaihi D, et al. This is an open-access article distributed under the terms of the Creative Commons Attribution License, which permits unrestricted use, distribution, and reproduction in any medium, provided the original author and source are credited. 
(ADA) guidelines [7]. The cohort consisted of 88 volunteers aged between 30-60 years of either sex and of Indian origin. They were divided into four groups: (Group-1)-obese diabetic, (Group-2)-nonobese diabetic, (Group-3)-obese non-diabetic and (Group-4)-healthy control. Patients with any history of acute or chronic infections, auto immune disorders, liver disease, pregnant and lactating females were excluded from the study. Informed consent was obtained from each participant before initiation of the study. The study was cleared by the institutional ethical committee. Age, sex, family history and physical examination including height and weight measurements and the Body Mass Index (BMI) was calculated using the formula weight $(\mathrm{kg})$ divided by height in meters squared, have been systematically recorded in a pre-designed Performa. A detailed clinical history had been obtained after biochemical investigation to rule out any disease other than diabetes. Estimation of plasma glucose fasting and post prandial ( 2 hours after meals) was done by the glucose oxidase method [8]. Glycosylated haemoglobin (HbA1C) was determined by Ion-Exchange Chromatography using kits from Crest Biosystem (INDIA) [9]. The Liver function tests: total proteins, glutamate pyruvate transaminase, alkaline phosphatase were estimated using automated analyser [10]. Lipid profile-total serum cholesterol, triglycerides, HDL, LDL, VLDL cholesterol were also measured using automated analyser [11]. Serum Insulin was estimated by ELISA method using standard Kit (UBI MAGIWEL) [12]. The inflammatory markers-estimation of serum hsCRP levels and IL-6 was done by ELISA, method using standard Kit (Cal Biotech USA) [13,14]. Serum adiponectin was estimated by ELISA method using standard Kit (Bio Vendor) [15]. Statistical analysis was performed using the two-way analysis of variance (ANOVA). Data were expressed as mean \pm Standard deviation, $\mathrm{p}<0.01$ was considered statistically significant.

\section{RESULTS}

In the study of demographic profile and diabetic status of study groups all the study groups were matched for age, sex and body mass index. Study groups included age matched healthy controls of both sexes and obese diabetic, non-obese diabetic and obese nondiabetic. Body Mass Index (BMI) is the indicator for generalized obesity. In our study, BMI was significantly high $(\mathrm{p}<0.001)$ in obese diabetic and obese non-diabetic as compared to non-obese diabetic and control (Table 1). No statistical significant findings were observed in the liver function test in all the study groups. In comparison of the lipid profile in the study groups, serum cholesterol levels in the control group showed high significant difference with the obese diabetic group $(\mathrm{p}<0.001)$, triglyceride levels, obese diabetic, non-obese diabetic and obese non-diabetic showed high significant difference with the control group $(\mathrm{p}<0.001)$ (Table 1). Glucose levels, glycosylated hemoglobin and serum Insulin levels indicate the diabetic status. Fasting and post prandial glucose levels are significantly higher in obese diabetic and non-obese diabetic $(\mathrm{p}<0.001)$ as compared to obese non-diabetic and control groups (Table 1). Glycosylated hemoglobin which is an indicator of the average glycemic control was significantly higher in obese diabetic and non-obese diabetic $(p<0.001)$ as compared to obese non-diabetic and control groups (Table 1). Serum Insulin which is an indicator of insulin resistance was significantly higher in obese diabetic patients and non-obese diabetic $(p<0.001)$ as compared to obese non-diabetic and control groups (Table 1). The levels of hsCRP and IL-6 are significantly higher in obese diabetic, non-obese diabetic and obese non-diabetic as compared to the healthy control group $(p<0.003)$ (Table 2$)$. The level of serum adiponectin is significantly higher in non-obese diabetic and healthy control groups $(\mathrm{p}<0.001)$ as compared to obese diabetic and obese non-diabetic (Table 2). This study confirms the previously reported inverse correlation between obesity associated changes and plasma adiponectin levels. In the correlation of adiponectin with inflammatory markers, a high significant negative correlation was seen between adiponectin and IL-6 in obese diabetic $(p<0.001)$ (Table 3). Significant negative

Table 1: Clinical and biochemical characteristics of the study groups.

\begin{tabular}{|c|c|c|c|c|c|}
\hline Variable & Group1 $(\mathrm{OD}) \mathrm{n}=22$ & $\begin{array}{c}\text { Group } 2(\mathrm{NOD}) \\
\mathrm{n}=22\end{array}$ & $\begin{array}{c}\text { Group } 3 \text { (ONGT) } \\
\mathrm{n}=22\end{array}$ & $\begin{array}{c}\text { Group } 4 \text { (CONTROL) } \\
n=22\end{array}$ & $\begin{array}{c}\text { Using one way } \\
\text { ANOVA ( } \mathrm{p} \text { Value) }\end{array}$ \\
\hline Age (Years) & $44.18 \pm 8.34$ & $42.41 \pm 7.11$ & $41.86 \pm 9.79$ & $38.82 \pm 15.98$ & NS \\
\hline BMI $\left(\mathrm{kg} / \mathrm{m}^{2}\right)$ & $30.1 \pm 3.33^{\mathrm{bd}}$ & $22.10 \pm 1.98^{\mathrm{ac}}$ & $29.69 \pm 4.16^{\mathrm{bd}}$ & $21.82 \pm 2.41^{\mathrm{ac}}$ & $<0.001$ \\
\hline Systolic BP (mm Hg) & $126.72 \pm 8.20$ & $124.90 \pm 12.8^{\mathrm{d}}$ & $121.72 \pm 4.58$ & $115.81 \pm 7.58^{\mathrm{ab}}$ & 0.001 \\
\hline Diastolic BP (mmHg) & $81.36 \pm 6.39$ & $81.45 \pm 7.04$ & $80.63 \pm 5.06$ & $77.54 \pm 4.85$ & NS \\
\hline Fasting Glucose Blood (mg/dL) & $173.73 \pm 1.50^{\mathrm{cd}}$ & $192.91 \pm 98.03^{\mathrm{cd}}$ & $92.45 \pm 10.12^{\mathrm{ab}}$ & $85.82 \pm 6.29^{\mathrm{ab}}$ & $<0.001$ \\
\hline Post Prandial Blood Glucose (mg/dL) & $308.73 \pm 108.05^{\mathrm{cd}}$ & $338.09 \pm 145.04^{\mathrm{cd}}$ & $125.55 \pm 28.41^{\mathrm{ab}}$ & $109.09 \pm 19.51^{\mathrm{ab}}$ & $<0.001$ \\
\hline Glycosylated Hemoglobin (\%) & $10.70 \pm 1.53^{\mathrm{cd}}$ & $10.43 \pm 2.34^{\mathrm{cd}}$ & $6.81 \pm 1.71^{\mathrm{ab}}$ & $5.87 \pm 0.70^{\mathrm{ab}}$ & $<0.001$ \\
\hline Insulin $(\mu \mathrm{IU} / \mathrm{L})$ & $37.34 \pm 12.21^{\text {cd }}$ & $36.70 \pm 10.19^{\mathrm{cd}}$ & $16.80 \pm 3.54^{\mathrm{ab}}$ & $15.80 \pm 2.79^{\mathrm{ab}}$ & $<0.001$ \\
\hline Total Proteins $(\mathrm{TP})(\mathrm{g} / \mathrm{dL})$ & $7.40 \pm 0.67$ & $7.62 \pm 0.70$ & $7.48 \pm 0.52$ & $7.54 \pm 0.64$ & NS \\
\hline $\begin{array}{l}\text { Serum glutamate pyruvate Transaminase } \\
\text { (IU/L) }\end{array}$ & $25.09 \pm 6.30$ & $25.86 \pm 13.18$ & $25.64 \pm 5.97$ & $19.86 \pm 6.08$ & NS \\
\hline Alkaline Phosphatase (IU/L) & $204.00 \pm 63.06$ & $180.59 \pm 53.30$ & $184.55 \pm 54.19$ & $188.09 \pm 50.46$ & NS \\
\hline Cholesterol (mg/dL) & $196.77 \pm 42.78^{\mathrm{bcd}}$ & $161.50 \pm 36.83^{\mathrm{ad}}$ & $162.36 \pm 29.49$ ad & $126.64 \pm 20.64^{\mathrm{abc}}$ & $<0.001$ \\
\hline $\operatorname{HDL}(\mathrm{mg} / \mathrm{dL})$ & $36.14 \pm 9.22$ & $39.77 \pm 9.83$ & $39.73 \pm 7.83$ & $39.82 \pm 71$ & NS \\
\hline $\mathrm{LDL}(\mathrm{mg} / \mathrm{dL})$ & $112.05 \pm 31.91$ & $104.0 \pm 16.79$ & $105.8 \pm 18.63$ & $98.18 \pm 13.42$ & NS \\
\hline VLDL (mg/dL) & $35.56 \pm 18.33^{\mathrm{bd}}$ & $24.82 \pm 6.51^{\mathrm{a}}$ & $29.95 \pm 9.29$ & $26.32 \pm 4.02^{\mathrm{a}}$ & 0.008 \\
\hline $\mathrm{TG}(\mathrm{mg} / \mathrm{dL})$ & $184.41 \pm 86.83^{\mathrm{d}}$ & $153.86 \pm 38.75^{\mathrm{d}}$ & $175.18 \pm 42.76^{\mathrm{d}}$ & $106.18 \pm 29.06^{\mathrm{abc}}$ & $<0.001$ \\
\hline
\end{tabular}

a: For Group-1 obese diabetic; b: For Group-2 non-obese diabetic; c: For Group-3 obese non diabetic; d: For Group-4 non obese non diabetic, healthy control. 
correlation is seen between adiponectin and hsCRP in obese nondiabetic ( $\mathrm{p}<0.047)$ (Table 4). In non-obese diabetic adiponectin showed significant negative correlation with both IL-6 $(\mathrm{p}<0.001)$ and hsCRP $(\mathrm{p}=0.140)$ (Table 5). In healthy controls, no significant correlation was seen (Table 6). In correlation studies of the entire group, a high significant negative correlation is seen between adiponectin and IL-6 $(\mathrm{p}<0.001)$ significant positive correlation is seen between IL-6 and hsCRP ( $p=0.014)$ (Table 7) (Figures 1-6).

Table 2: Comparision of the biomarkers levels in study groups.

\begin{tabular}{|c|c|c|c|c|c|}
\hline Variable & Group $1(\mathrm{OD}) \mathrm{n}=22$ & Group $2(\mathrm{NOD}) \mathrm{n}=22$ & Group $3(\mathrm{ONGT}) \mathrm{n}=22$ & $\begin{array}{c}\text { Group } 4 \text { (CONTROL) } \\
n=22\end{array}$ & $\begin{array}{c}\text { Using one way ANOVA } \\
\text { ( } \mathrm{p} \text { Value })\end{array}$ \\
\hline $\mathrm{hsCRP}(\mu \mathrm{g} / \mathrm{mL})$ & $5.36 \pm 5.38^{\mathrm{cd}}$ & $3.32 \pm 2.88$ & $2.40 \pm 2.96^{\mathrm{a}}$ & $1.51 \pm 1.63^{\mathrm{a}}$ & 0.003 \\
\hline IL-6 (pg/mL) & $3.42 \pm 2.24^{\mathrm{d}}$ & $2.77 \pm 1.79^{\mathrm{d}}$ & $2.04 \pm 2.70$ & $1.07 \pm 0.76^{\mathrm{ab}}$ & 0.002 \\
\hline Adiponectin $(\mu \mathrm{g} / \mathrm{mL})$ & $7.59 \pm 1.82^{\mathrm{bd}}$ & $16.86 \pm 8.56^{\mathrm{ac}}$ & $9.42 \pm 3.01^{\mathrm{bd}}$ & $17.96 \pm 5.68^{\mathrm{ac}}$ & $<0.001$ \\
\hline
\end{tabular}

Table 3: Correlation studies in group-1 (obese diabetic).

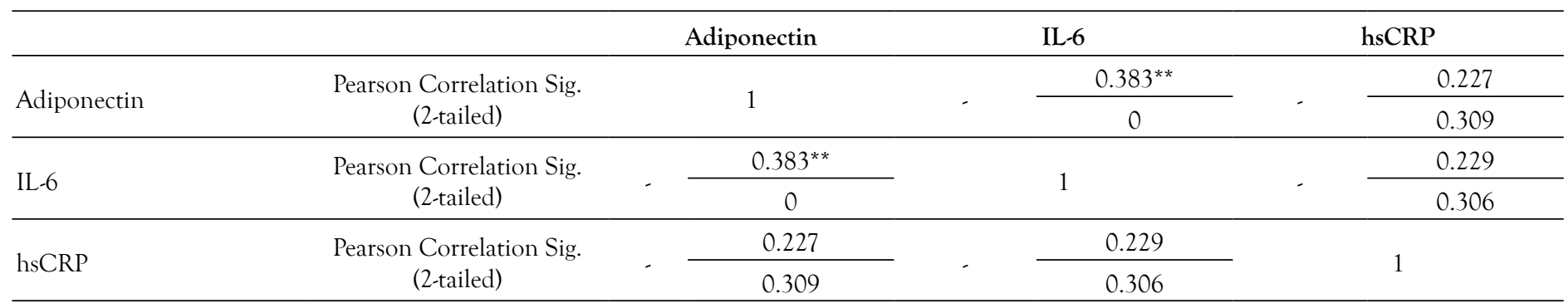

Valves are expressed as Pearson's correlation Co-efficient (r-value) (n=22)

${ }^{* *}$ Correlation is significant at the 0.01 level

A high significant negative correlation is seen between Adiponectin and IL-6 $(\mathrm{p}<0.001)$

Table 4: Correlation studies in group-2 (non-obese diabetic).

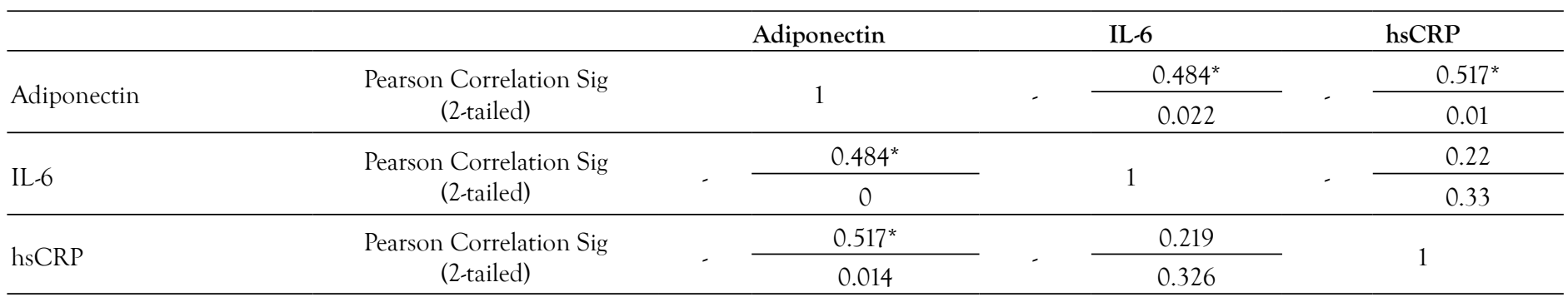

Valves are expressed as Pearson's correlation co-efficient (r-value) $(n=22)$.

* Correlation is significant at 0.05 level.

A significant negative correlation is seen between Adiponectin and IL-6 ( $\mathrm{p}=0.022)$

A significant negative correlation is seen between Adiponectin and hsCRP $(\mathrm{p}=0.014)$.

Table 5: Correlation studies in group-3 (obese non diabetic).

\begin{tabular}{|c|c|c|c|c|c|}
\hline & & Adiponectin & & IL-6 & hsCRP \\
\hline \multirow{2}{*}{ Adiponectin } & \multirow{2}{*}{$\begin{array}{c}\text { Pearson Correlation Sig } \\
\text { (2-tailed) }\end{array}$} & \multirow{2}{*}{1} & \multirow{2}{*}{ - } & 0.031 & $0.429^{*}$ \\
\hline & & & & 0.89 & 0.309 \\
\hline \multirow{2}{*}{ IL-6 } & \multirow{2}{*}{$\begin{array}{l}\text { Pearson Correlation Sig } \\
\text { (2-tailed) }\end{array}$} & 0.031 & & \multirow{2}{*}{1} & 0.009 \\
\hline & & 0.89 & & & 0.967 \\
\hline \multirow{2}{*}{ hsCRP } & \multirow{2}{*}{$\begin{array}{l}\text { Pearson Correlation Sig } \\
\text { (2-tailed) }\end{array}$} & $0.429^{*}$ & \multirow{2}{*}{ - } & 0.009 & \multirow{2}{*}{1} \\
\hline & & 0.047 & & 0.967 & \\
\hline
\end{tabular}

Valves are expressed as Pearson's correlation

${ }^{*}$ Correlation is significant at the 0.05 level.

A significant negative correlation is seen between Adiponectin and hsCRP $(\mathrm{p}=0.047)$ 
Table 6: Correlation studies in group-4 (non obese, non diabetic, healthy control).

\begin{tabular}{|c|c|c|c|c|c|}
\hline & & Adiponectin & & IL-6 & hsCRP \\
\hline \multirow{2}{*}{ Adiponectin } & \multirow{2}{*}{$\begin{array}{c}\text { Pearson Correlation Sig } \\
\text { (2-tailed) }\end{array}$} & \multirow{2}{*}{1} & \multirow{2}{*}{ - } & 0.305 & 0.036 \\
\hline & & & & 0.167 & 0.874 \\
\hline \multirow{2}{*}{ IL-6 } & \multirow{2}{*}{$\begin{array}{c}\text { Pearson Correlation Sig } \\
\text { (2-tailed) }\end{array}$} & 0.305 & & \multirow{2}{*}{1} & 0.278 \\
\hline & & 0.167 & & & 0.21 \\
\hline \multirow{2}{*}{ hsCRP } & \multirow{2}{*}{$\begin{array}{l}\text { Pearson Correlation Sig } \\
\text { (2-tailed) }\end{array}$} & 0.036 & \multirow[b]{2}{*}{ - } & 0.278 & \multirow{2}{*}{1} \\
\hline & & 0.874 & & 0.21 & \\
\hline
\end{tabular}

Valves are expressed as Pearson's correlation Co-efficient ( $r$ value) $n=22$. No significant correlation was seen among the parameters

Table 7: Correlation studies of the entire study groups.

\begin{tabular}{|c|c|c|c|c|c|c|}
\hline \multirow[b]{2}{*}{ Adiponectin Pearson } & \multicolumn{2}{|c|}{ Adiponectin } & \multicolumn{2}{|c|}{ IL-6 } & \multicolumn{2}{|c|}{ hsCRP } \\
\hline & 1 & & - & $0.383^{* *}$ & - & 0.009 \\
\hline Correlations Sig (2-tailed) & & & & 0 & & 0.932 \\
\hline IL-6 Pearson & - & $0.383^{* *}$ & 1 & & $0.262^{*}$ & \\
\hline Correlation Sig (2-tailed) & & 0 & & & 0.014 & \\
\hline hsCRP Pearson & 0.01 & & $0.262^{*}$ & & 1 & \\
\hline Correlation Sig (2-tailed) & 0.93 & & 0.014 & & & \\
\hline \multicolumn{7}{|c|}{ Valves are expressed as Pearson's correlation Co-efficient (r-value) (n=88). } \\
\hline \multicolumn{7}{|c|}{${ }^{*}$ Correlation is significant at the 0.05 level. } \\
\hline${ }^{*}$ Correlation is significant & & & & & & \\
\hline
\end{tabular}

A high significant negative correlation is seen between Adiponectin and IL-6 ( $p<0.001)$. A significant positive correlation is seen between IL-6 and hsCRP $(p=0.014)$.

Comparison of Blood Glucose levels in study groups

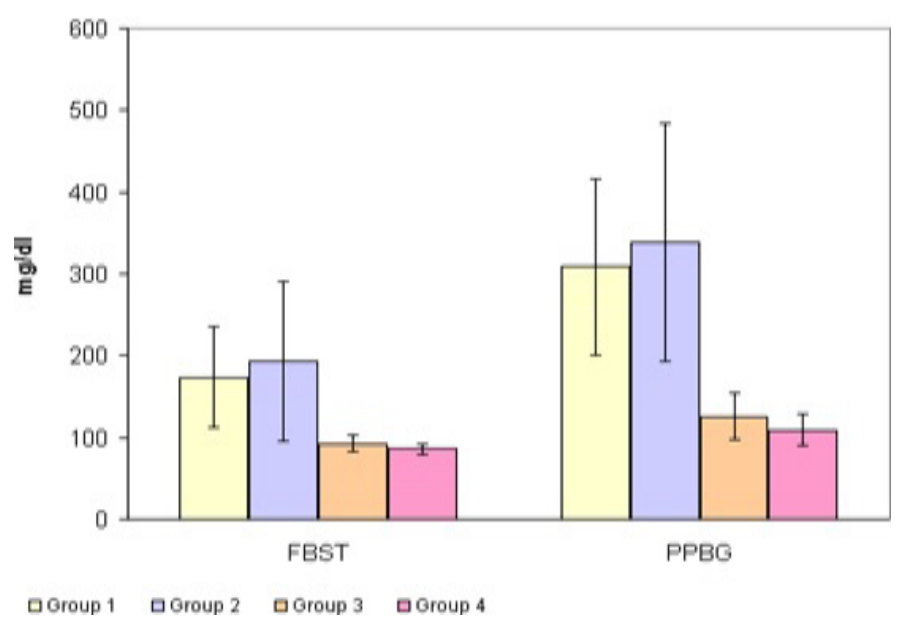

Figure 1: Comparison of blood glucose level in study groups.

Comparison of GHb in study groups

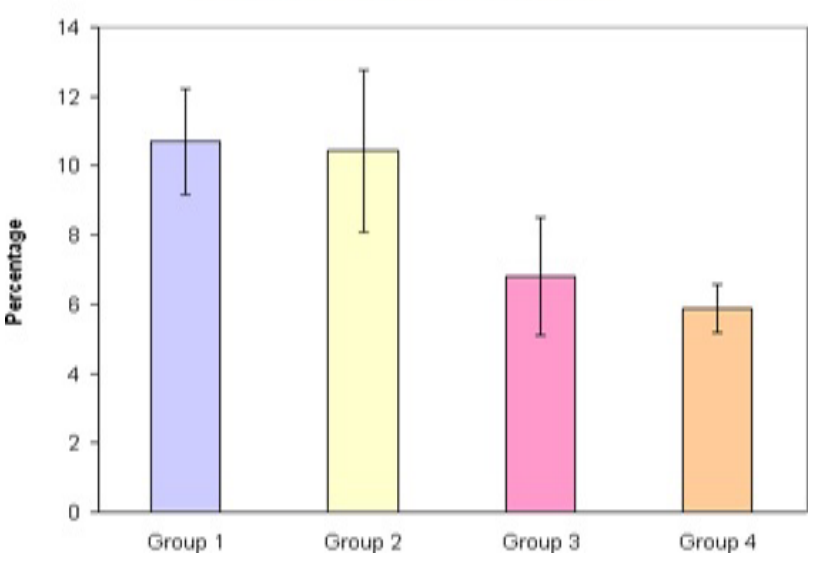

Figure 2: Comparison of $\mathrm{GHb}$ in study groups.

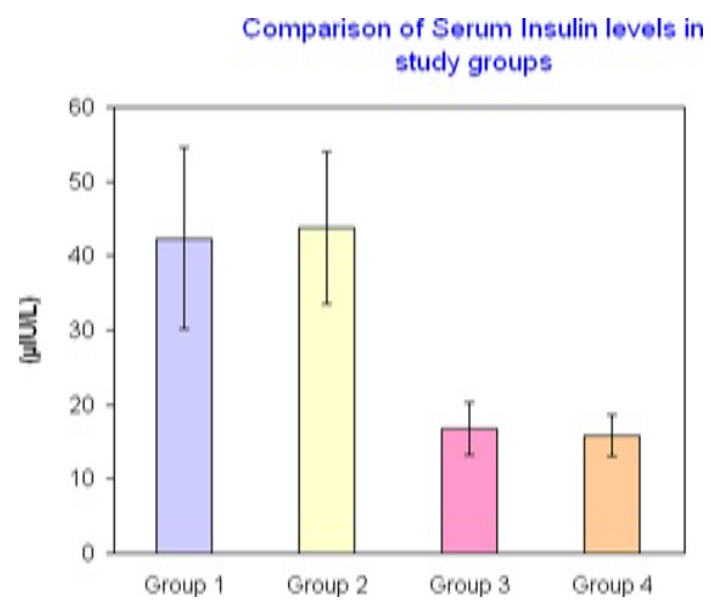

Figure 3: Comparison of serum insulin levels in study groups.

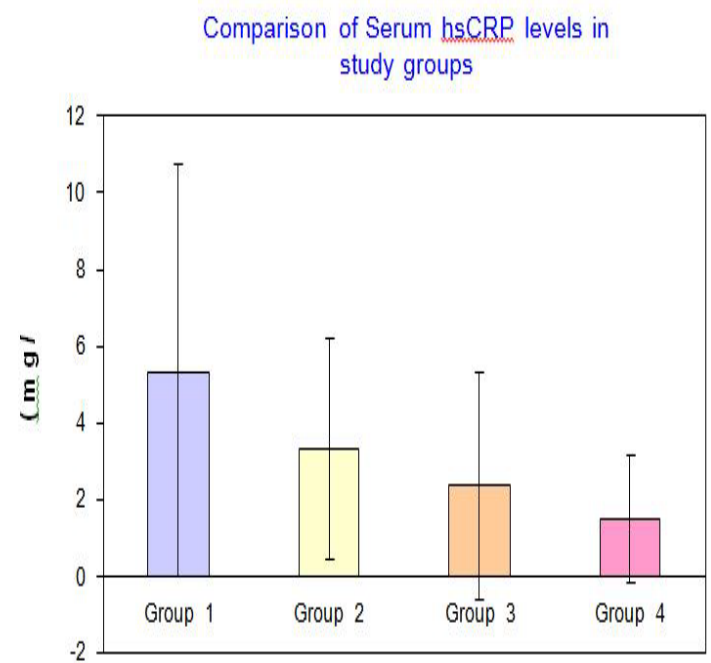

Figure 4: Comparison of serum hsCRP levels in study groups. 




Figure 5: Comparison of serum IL-6levels in study groups.

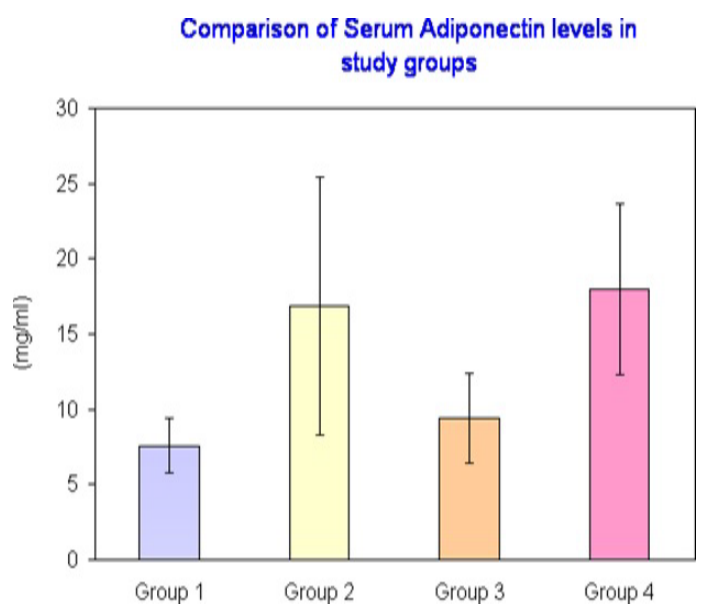

Figure 6: Comparison of serum adiponectin levels in study groups.

\section{DISCUSSION}

Circulating levels of adiponectin decrease with increasing visceral obesity and are lower in patients with type 2 diabetes, as compared with controls matched by body mass index. Several reports demonstrated anti-inflammatory effects of adiponectin. Because increased adipose tissue is associated with low-grade chronic inflammation and pro-inflammatory factors inhibit adiponectin production, the current hypothesis states that chronic inflammation associated with visceral obesity inhibits production of adiponectin, perpetuating inflammation. The negative correlation between adiponectin and markers of inflammation in the aforementioned conditions supports this hypothesis. In contrast with disorders typically associated with excess adiposity and positive energy balance, adiponectin levels are elevated rather than decreased in classic chronic inflammatory/autoimmune diseases that are unrelated to increased adipose tissue, such as rheumatoid arthritis, SLE, inflammatory bowel disease, type 1 diabetes, and cystic fibrosis. In these patients, adiponectin levels positively rather than negatively correlate with inflammatory markers. Furthermore, proinflammatory effects of adiponectin have been reported in tissues such as joint synovium and colonic epithelium. Thus, adiponectin is regulated in the opposite direction and may exert differential functions in classic versus obesity-associated inflammatory conditions [16].

A consistent association of BMI and upper body adiposity with diabetes has been shown in the Indians population. A minimal rise in the BMI could act adversely with the genetic susceptibility to diabetes. For Asians BMI $>3$ is considered overweight and $>25$ are obese [17]. In the study, we have taken a group non-obese diabetic, where the subjects are diabetic but not obese and had significantly lower BMI. Although most patients with type 2 diabetes mellitus are obese and obesity itself causes some degree of insulin resistance, patients of type 2 diabetes mellitus but are not obese by the traditional weight criteria may have increased percentage of body fat distributed predominantly in the abdominal region [18]. Obesity is often associated with insulin resistance and a cluster of metabolic disturbance, our study showed significantly lower levels of serum insulin in obese non-diabetic. This can probably be explained by the existence of a subgroup of healthy but obese individuals [19]. It is however unclear why some obese individuals fail to show traditional risk factors associated with the insulin resistance syndrome despite having a very high accumulation of body fat [20]. In the 1980's the existence of a Metabolically Healthy but Obese individuals (MHO) was postulated. Subsequent studies confirmed the existence of a subgroup of obese individuals with relatively high levels of insulin sensitivity and a favourable metabolic profile. Numerous studies suggest that the amount of visceral fat is an important factor associated with variation in insulin sensitivity [21]. It has been observed that there is a $50 \%$ lower accumulation of visceral adipose tissue in metabolically healthy obese as compared to metabolically abnormal group. There is also good evidence that the difference in the body fat distribution plays a part [22]. Several studies have shown that obese people with an abdominal pattern of fat accumulation are more likely to have prediabetic abnormalities such as insulin resistance, hyperinsulinemia and glucose intolerance than those with a more femero-gluteal pattern [23]. Studies have shown that difference in adipose tissue cellularity also plays a role, people who become obese primarily through an increase in fat cell size (hypertrophic obesity) are more likely to develop obesity related metabolic disorders than those in whom the increase in adiposity is primarily mediated by an increase in fat cell number (hyper plastic obesity) [24]. Clinically, hypo-adiponectinaemia was observed in patients with obesity, diabetes, and coronary artery disease. The obese non-diabetic group in spite of being non-diabetic has lower value of adiponectin, which can be explained as occurrence due to the obesity status. A number of clinical studies showed a decrease of adiponectin levels in obese humans in relative to lean subjects. For example, Arita et al. found a negative correlation between BMI and plasma adiponectin levels in Japanese men and women this was further supported by studies of Weyer et al. performed on Caucasian and Pima Indian Population [25,26]. It is possible that adiponectin concentration may be convenient marker for identifying subjects with the metabolic syndrome who may later progress to impaired glucose tolerance.

Studies by Upadhyaya et al. in their study to identify the association of inflammatory markers (adiponectin and IL-6) with fasting glucose in normoglycemic, prediabetic and hyperglycaemic people in Indian population showed that there was a significant but gradual change in both adiponectin i.e., reduction and IL-6 increased levels in normoglycemic, prediabetic and hyperglycaemic population during the progression of healthy toward diabetic population via pre-diabetic condition [27].

It is now well established that obesity is associated with a chronic inflammatory response, characterized by abnormal adipokines production and the activation of some pro-inflammatory signalling pathway resulting in the induction of several biological markers of inflammation. There are altered levels of several circulating 
factors such as an increase in the plasma levels of CRP, TNF, IL-6 and other biological markers of inflammation [28]. IL-6 has been reported to increase liver CRP production. Interestingly, adipose IL-6 content is higher in obese patients displaying an increased CRP levels. It is now well known the IL- 6 production by adipose tissue is enhanced in obesity and is thought that 15 to 30 percent of circulating IL-6 levels is derived from adipose tissue even in the absence of an acute inflammation [29]. Substantial experimental evidence suggests that IL- 6 \& CRP, the two sensitive physiological markers of clinical systemic inflammation are also associated with hyperglycemia, insulin resistance and overt type 2 diabetes mellitus [30]. Recent prospective studies have shown a relationship between hsCRP and IL- 6 and the risk of developing type 2 diabetes mellitus [31]. Substantial experimental evidence and cross sectional data suggest that IL- 6 \& CRP, the two sensitive physiological markers of clinical systemic inflammation are associated with hyperglycemia, insulin resistance and overt type 2 diabetes mellitus. Indeed, it has been postulated that type 2 diabetes mellitus may represent a disease of the innate immune system [2]. Kern et al. had reported that increased adiposity is associated with increased plasma levels of inflammatory markers such as IL-6 and hsCRP [32].

Considering that obesity is intimately related to insulin resistance, and that some markers of inflammation are secreted at least in part by adipose tissue or influence adipose tissue physiology the possibility exists that instead of being related to insulin resistance, the concentration of serum markers of inflammation could also depend on obesity-this is in explanation to the study finding that in obese non-diabetic subjects, the values of proinflammatory markers hsCRP and IL-6 are increased [33]. Obesity mediated cytokine production is therefore an important control mechanism for systemic elevation of both these biomarkers. The primary cytokine involved in hepatic CRP synthesis is IL-6, also an important adipocyte-signaling molecule released from visceral and subcutaneous fat stores. Indeed, approximately $25 \%$ of in-vivo systemic IL-6 originates from subcutaneous adipose tissue and is thought to modify adipocyte glucose and lipid metabolism with body weight [34]. Furthermore, omental fat cells have been shown to secrete as much as 2 to 3 times more IL- 6 in-vitro than cell derived from subcutaneous stores, an intriguing finding as venous drainage from omental fat provides direct access to the portal system, and abdominal adiposity hence is linked to insulin resistance [35]. Adiponectin has been shown to down regulate inflammatory response in-vitro as has been reported by Quchi et al. [36] which is suggestive of the fact that obesity induces insulin resistance and inflammatory cytokines are secreted by adipose tissues, though it difficult to evaluate if the relationship between serum markers of inflammation and insulin resistance result either from pathophysiological link or is merely reflecting the stronger relationship between obesity and insulin resistance [37]. As is seen in the present study, adiponectin an adipocytokine secreted by adipose tissue and known to be protective against diabetes is inversely correlated with IL-6 in obese diabetic, in non-obese diabetic adiponectin negatively correlated with hsCRP. In both groups, obesity is the common factor where there is an inverse correlation between adiponectin and inflammatory cytokines hsCRP and IL-6. Interestingly, in non-obese diabetic, adiponectin showed negative correlation with both hsCRP and IL-6, suggesting that the diabetic condition might have led to the increase in the inflammatory cytokines which is lineage with earlier findings.

\section{LIMITATIONS}

There was a preliminary study done in North Indian population. The study would have made a better impact if other anthropometric measurements such as waist to hip ratio and waist circumference were measured for assessment of obesity also gender differences could have been considered. Moreover, it is known that the High Molecular Weight (HMW) is the more physiologically active form of adiponectin, in the present study total adiponectin was measured.

\section{CONCLUSION}

Thus, our findings of an inverse correlation between plasma adiponectin levels and hs-CRP and IL- 6 may suggest that decreased production of adiponectin contributes to the systemic and vascular inflammation found in both obesity and diabetes. It also suggests that decrease levels of adiponectin may serve as marker of increase metabolic and inflammatory risk. Adiponectin may therefore be an important link between obesity, inflammation and type 2 diabetes mellitus. Hence, measurement of adiponectin can be an asset a potent biomarker of clinical manifestation of metabolic syndrome.

\section{CONFLICTS OF INTEREST}

There are no conflicts of interest.

\section{REFERENCES}

1. Nikolajczyk BS, Jagannathan-Bogdan M, Shin H, Gyurko R. State of the union between metabolism and the immune system in type 2 diabetes. Genes Immun. 2011;12:239-250.

2. Donath MY, Sheolson SE. Type 2 diabetes as an inflammatory disease. Nat Rev Immunol. 2011;11:81-83.

3. Kadowaki T, Yamauchi T, Kubota N, Hara K, Ueki K, Tobe K. Adiponectin receptors in insulin resistance, diabetes and the metabolic syndrome. J Clin Invest. 2006;116:1784-1792.

4. Spranger J, Kroke A, Möhlig M, Hoffmann K, Bergmann MM, Ristow $\mathrm{M}$, et al. Inflammatory cytokines and the risk to develop type 2 diabetes: results of the prospective population-based European Prospective Investigation into cancer and Nutrition (EPIC)-Potsdam Study. Diabetes. 2003;52:812-817.

5. Tabassum R, Mahendran Y, Dwivedi OP, Chauhan G, Ghosh S, Marwaha RK, et al. Common variants of IL6, LEPR and PBEF1 are associated with obesity in Indian children. Diabetes. 2012;61:626-631.

6. Tillin T, Hughes AD, Godsland IF, Whincup P, Forouhi NG, Welsh P, et al. Insulin resistance and truncal obesity as important determinants of the greater incidence of diabetes in Indian Asian and African Caribbeans compared with Europeans: the Southall and Brent revisited (SABRE) cohort. Diabetes Care. 2013;36:383-393.

7. Expert Committee on the Diagnosis and the classification of Diabetes Mellitus. Report of the Expert committee on the diagnosis and classification of diabetes mellitus. Diabetes Care. 1997;20:1183-1197.

8. Burtis CA, Ashwood ER. Teitz textbook of Clinical Chemistry (6th edn). Philedelphia: WB Saunders \& Co. 2007;20:389-391.

9. Burtis CA, Ashwood ER. Teitz textbook of Clinical Chemistry (6th edn). Philedelphia: WB Saunders \& Co. 2012;20:395-397.

10. Burtis CA, Ashwood ER. Teitz textbook of Clinical Chemistry (6th edn). Philedelphia: WB Saunders \& Co. 1999;20:322-325.

11. Burtis CA, Ashwood ER. Teitz textbook of Clinical Chemistry (6th edn). Philedelphia: WB Saunders \& Co. 2018;20:422-425. 
12.Andersen L, Dinesen B, Jørgensen PN, Poulsen F, Røder ME. Enzyme Immunoassay for intact Human Insulin in serum or plasma. Clin Chem. 1993;38:578-582.

13. Ray A, Tatter SB, Santhanam U, Helfgott DC, May LT, Sehgal PB. Regulation of expression of interleukin-6: Molecular studies. Ann NY Acad Sci. 1998;557:353-362.

14. Yudkin JS, Stehouwer CD, Emeis JJ, Coppack SW. C-reactive protein in healthy subjects:Association with obesity,insulin resistance and endothelial dysfunction.Apotiential role of cytokines originating from adipose tissue. Arterioscler Thromb Vasc Biol. 1999;19:972-978.

15.Diez JJ, Iglesias P. The role of novel adipocyte-derived hormone adiponectin in human disease. Eur J Endocrinol. 2003;148:293-300.

16. Fantuzzi G. Adiponectin and inflammation: consensus and controversy. J Allergy Clin Immunol. 2008;121:326-30.

17. Vikram NK, Pandey RM, Misra A, Sharma R, Devi JR, Khanna N. Non Obese (body mass index $<25 \mathrm{~kg} / \mathrm{m} 2$ ) Asian Indians with normal waist circumference have high cardiovascular risk. Nutritrion. 2003;19:503509.

18. Phillips CM. Metabolically healthy obesity: definitions, determinants and clinical implications. Rev Endocr Metab Disord. 2013;14:219-227.

19.Muñoz-Garach A, Cornejo-Pareja I, Tinahones FJ. Does Metabolically Healthy Obesity Exist? Nutrients. 2016;8:E320.

20.Phillips CM. Metabolically Healthy Obesity: Personalised and Public Health Implications. Trends Endocrinol Metab. 2016;27:189-191.

21. Karelis AD, Faraj M, Bastard JP, St-Pierre DH, Brochu M, Prud'homme $\mathrm{D}$, et al. The metabolically healthy but obese individual presents a favorable inflammation profile. J Clin Endocrinol Metab. 2005;90:41454150.

22.Kelishadi R, Cook SR, Motlagh ME, Gouya MM, Ardalan G, Motaghian $\mathrm{M}$, et al. Metabolically obese normal weight and phenotypically obese metabolically normal youths. The Caspian study. J Am Diet Assoc. 2008;108:82-90.

23.Chan JM, Rimm EB, Colditz GA, Stampfer MJ, Willett WC. Obesity, far distribution and weight gain risk factors for clinical diabetes in men. Diabetes Care. 1994;17:961-969.

24. Krotkiewski M, Björntorp P, Sjöström L, Smith U. Impact of obesity on metabolism in men and women: importance of regional adipose tissue distribution. J Clin Invest. 1983;72:1150-1162.

25.Arita Y, Kihara S, Ouchi N, Takahashi M, Maeda K, Miyagawa J, et al. Paradoxical decrease of an adipose specific protein, adiponectin, in obesity. Biochem Biophys Res Commun. 1999;257:79-83.

26. Weyer C, Funahashi T, Tanaka S, Hotta K, Matsuzawa Y, Pratley RE, et al. Hypoadiponectinemia in obeasity and type 2 diabetes: close association with insulin resistance and hyperinsulinemia. J Clin Endocrinol Metab. 2001;86:1930-1935.

27. Upadhyaya S, Kadamkode V, Mahammed R, Doraiswami C, Banerjee G. Adiponectin and IL-6 Mediators of inflammation in progession of healthy to type 2 diabetes in Indian population. Adipocyte. 2014;3:3945.

28. Ford ES. The metabolic syndrome and C-reactive protein, fibrinogen and leukocyte count: findings from the third National health and Nutrition Examination Survey. Atherosclerosis. 2003;168:351-358.

29.Bastard JP, Maachi M, Van Nhieu JT, Jardel C, Bruckert E, Grimaldi A, et al. Adipose tissue IL- 6 contents correlates with resistance to insulin activation of glucose uptake both in vivo and vitro. J Clin Endocrinol Metab. 2002;87:2084-2085.

30.Choudhary N, Ahlanvet R. Interlevkin-6 and C-reactive protein in pathogenesis of diabetic nephropathy: new evidence linking inflammation glycemic control and microalbominoria. Iran J Kidney Dis. 2008;2:72-79.

31. Pradhan AD, Manson JE, Rifai N, Buring JE, Ridker PM. C-reactive Protein interleukin 6 and risk of developing type 2 diabetes mellitus. JAMA. 2001;286:327-334.

32.Kern PA, Ranganathan S, Li C, Wood L, Ranganathan G. Adipose tissue tumor necrosis factor and interleukin-6 expression in human obesity and insulin resistance. Am J Physiol. 2001;280:745-751.

33. Festa A, D'Agostino R Jr, Williams K, Karter AJ, Mayer-Davis EJ, Tracy $\mathrm{RP}$, et al. The relation of body fat mass and distribution to markers of chronic inflammation. Int J Obesrelat Metab Discord. 2001;25:14071415 .

34.Orban Z, Remaley AT, Sampson M, Trajanoski Z, Chrousos GP. The difference effect of food intake and beta-adrenergic stimulation on adipose-derived hormones and cytokine in man. J Clin Endocrinol Metab. 1999;84:2126-2133.

35.Fried SK, Bunkin DA, Greenberg AS. Omental and subcutaneous adipose tissues of obese subjects release interleukin-6: depot difference and regulation by glucorticoid. J Cinendorinoi Metab. 1998;83:847850 .

36. Ouchi N, Kihara S, Arita Y, Maeda K, Kuriyama H, Okamoto Y, et al. Novel modulator for endothelial adhesion molecules: adipocytederived plasma protein adiponectin. Circulation. 1999;100:2473-2476.

37. Mechanick JI, Zhao S, Garvey WT. The adopokine-Cardiovascular life style network: translation to clinical practise. J Am Coll Cardio. 2016;68:1785-1803. 